JIKAP PGSD: Jurnal Ilmiah Ilmu Kependidikan

Vol,3. No,2. Tahun 2019

e-ISSN: 2597-4440 dan p-ISSN: 2597-4424

This work is licensed under a Creative Commons Attribution

4.0 International License

\title{
Penerapan Metode Inkuiri Dalam Peningkatan Hasil Belajar IPS Pada Pokok Bahasan Kegiatan Ekonomi Penduduk Siswa Kelas V SD Inpres 10/73 Welado Kabupaten Bone
}

\author{
Mohammad Arsyad \\ Dinas Pendidikan Kabupaten Bone \\ Email: mohammad.arsyad@gmail.com
}

\begin{abstract}
Abstrak. Masalah penelitian ini yaitu (1) apakah dengan metode inkuiri dapat meningkatkan proses belajar IPS siswa kelas VI SD Inpres 10/73 Welado Kabupaten Bone dan (2) apakah dengan metode inkuiri dapat meningkatkan hasil belajar IPS siswa kelas VI SD Inpres 10/73 Welado Kabupaten Bone. Penelitian ini bertujuan untuk mengetahui peningkatan hasil belajar IPS siswa VI SD Inpres 10/73 Welado Kabupaten Bone dengan menggunakan metode inkuiri. Jenis penelitian ini adalah penelitian tindakan kelas. Subjek penelitian ini adalah seluruh siswa kelas VI SD Inpres 10/73 Welado Kabupaten Bone tahun pelajaran 2016-2017 sebanyak 25 orang siswa. Penelitian ini dilaksanakan dalam 2 siklus, siklus I dilaksanakan 3 kali pertemuan dan siklus II dilaksanakandalam 3 kali pertemuan yang masing-masing siklus terdiri atas perencanaan, tindakan, observasi/evaluasi, dan refleksi. Pengumpulan data dilakukan dengan cara observasi dan tes hasil belajar. Hasil penelitian menunjukkan bahwa: (1) melalui penggunaan metode inkuiri, hasil belajar siswa meningkat, dan (2) hasil belajar IPS meningkat dari kategori sedang kekategori tinggi. Dengan demikian, penerapan metode inkuiri dapat meningkatkan hasil belajar IPS, khususnya materi uang pada siswa kelas VI SD Inpres 10/73 Welado Kabupaten Bone.
\end{abstract}

Kata kunci: metode inquiri, hasil belajar

\begin{abstract}
The problems of this study are (1) whether the inquiry method can improve the social studies learning the process of the sixth-grade students of SD Inpres 10/73 Welado Regency Bone and (2) whether the inquiry method can improve social studies learning outcomes of class VI SD Inpres 10/73 Welado Regency Bone. This study aims to determine the increase in social studies learning outcomes of students VI SD Inpres 10/73 Welado District Bone by using the inquiry method. This type of research is classroom action research. The subjects of this study were all students in grade VI SD Inpres 10/73 Welado District of Bone 2016-2017 as many as 25 students. This study was conducted in 2 cycles, cycle I was held 3 times and the second cycle was carried out in 3 meetings, each cycle consisting of planning, action, observation/evaluation, and reflection. Data collection is done by observation and test results. The results showed that: (1) through the use of inquiry methods, student learning outcomes increased, and (2) social studies learning outcomes increased from the medium category to high category. Thus, the application of inquiry methods can improve social studies learning outcomes, especially money material in class VI SD Inpres 10/73 Welado Bone District.
\end{abstract}

Keywords: inquiry method, learning outcomes 


\section{PENDAHULUAN}

Perkembangan ilmu pengetahuan dan teknologi menuntut peserta didik untuk membenah diri dalam menghadapi tantangan perkembangan zaman.Sementara itu, kurangnya pengetahuan dasar materi pelajaran IPS sebagai salah satu bidang ilmu yang memegang peranan penting dan memiliki andil besar terhadap perkembangan ilmu pengetahuan pada suatu jenjang pendidikan menunjukkan ketidakberhasilan siswa dalam belajar pada jenjang pendidikan tersebut.Selain itu, keberhasilan siswa dalam memahami materi pelajaran, tidak terlepas dari minat belajar siswa itu sendiri dan hal ini dapat dipengaruhi pula oleh kemampuan guru yang mengajarkan materi tersebut.

Salah satu komponen yang berkaitan dengan masalah mutu pendidikan tersebut adalah pengelolaan proses belajar mengajar yang pelaksanaannya menghadapi banyak masalah. Di antaranya adalah masalah strategi dan metode mengajar yang digunakan agar siswa dapat mencari, memilih, danmengembangkan sejumlah strategi pengajaran yang optimal sertamengembangkan pendekatan yang dapat membangkitkan motivasi siswa. Selain itu, agar siswa merasa benar-benar ikut ambil bagian dan berperan aktif dalam proses belajar mengajar.

Uraian tersebut merupakan dasar

diberlakukannya Undang-Undang Republik Indonesia Nomor 20 Tahun 2003 Tentang Sistem Pendidikan Nasional, Peraturan Pemerintah Republik Indonesia Nomor 19 Tahun 2005 Tentang Badan StandarNasional Pendidikan (BSNP), Peraturan Menteri Pendidikan Nasional Nomor 22, 23, dan 24 Tahun 2006 Tentang Standar Kompetensi, Standar Isi, dan Standar Kelulusan bahwa:

Satuan pendidikan menengah dituntut untuk mengembangkan serta memaksimalkan Kurikulum Tingkat Satuan Pendidikan sesuai dengan kebijakan yangada dan mengacu kepada ketentuan-ketentuan yang berlaku berikut panduan pengembangan silabus dan program pembelajaran dari kelas I sampai kelas VI sebagai acuan kerja bagi peserta didik di SD pada umumnya.

Masyarakat yang akan dibentuk dari pendidikan Ilmu Pengetahuan Sosial ini adalah masyarakat yang mendunia yang berpijak pada kearifan lokal. Dalam kearifanlokal tumbuh adanya kesadaran ruangan dan kesadaran
waktu.Kesadaran ruang adalah menyadari di mana dia tinggal, sedangkan kesadaran waktu adalah memahami bahwa diahidup dalam suatu masyarakat yang berubah.

Mata pelajaranl ImuPengetahuan Sosial bertujuan untuk mengembangkan potensi peserta didik agar peka terhadap masalah sosial yang terjadi di masyarakat, memiliki sifat mental positif terhadap perbaikan segala ketimpangan yang terjadi dan terampil mengatasi setiap masalah yang terjadi sehari-hari baik yang menimpa dirinya sendiri maupun yang menimpa kehidupan masyarakat.

Pembelajaran Ilmu Pengetahuan Sosial seharusnya menitikberatkan kepada metode yang dapat menumbuhkembangkan inisiatif, kreatif, intelektualitas, dan watak pribadi.Pendidikan Ilmu Pengetahuan Sosial di sekolah diberikan atas dasar pemikiran bahwa manusia merupakan makhluk sosial yang tidak dapat dipisahkan dari kehidupan manusia lainnya. Oleh karena itu, pendidikan Ilmu Pengetahuan Sosial merupakan bidang pengetahuan yang sangat kompleks sehingga guru dituntut menguasai berbagai kompetensi atau berbagai keterampilan yang nantinya bisa membuat pembelajaran di dalam kelas menjadi menarik dan membuat para peserta didik mempunyai semangat atau mempunyai motivasi dalam mempelajari mata pelajaran Ilmu Pengetahuan Sosial.

Berdasarkan pengalaman mengajar di kelas VI SD Inpres 10/73 Welado Kabupaten Bone bahwa selama ini proses pembelajaran IPS yang diterapkan pada umumnya bersifat konvensional dan dilihat dari standar nilai di kelas VI SD Inpres 10/73 Welado Kabupaten Bone nilai Ujian blok mata pelajaran IPS siswa kelas VI SD Inpres 10/73 Welado Apala Kabupaten Bone Tahun Pelajaran 2016-2017 adalah 65 yang termasuk rendah dan nilai yang telah ditetapkan di kelas VI SD Inpres 10/73 Welado Apala Kabupaten Bone yaitu 70. Rendahnya nilai mata pelajaran IPS di kelas VI SD Inpres 10/73 Welado Kabupaten Bone ini disebabkan oleh kurangnya perhatian siswa di dalam kelas karena metode yang digunakan belum sesuai dengan minat belajar murid. Di dalam proses belajar mengajar hanya guru yang lebih berperan aktif di dalam kelas. Guru hanya memberikan penjelasan-penjelasan kepada siswa tanpa mengetahui apa siswa yang bersangkutan sudah memahami penjelasan dan guru tersebut atau belum.

Salah satu keluhan dalam mempelajari IPS yang banyak terdengar adalah kurangnya 
keterkaitan antara materi yang dipelajari di sekolah dengan dunia nyata dan kehidupan sehari-hari siswa. Hal tersebut menunjukkan munculnya berbagai dampak yang kurang baik terhadap siswa. Di antaranya motivasi siswa untuk belajar IPS berkurang yang akhirnya berdampak pada rendahnya hasil belajar, sehingga dalam proses pembelajaran, seorang guru harus memiliki keterampilan-keterampilan khusus yang dapat mengantarkan siswa menfokuskan dalam dunia pendidikan harus menguasai berbagai keterampilan dan kemampuan, minimal penguasaan materi pelajaran dan keterampilan dalam mengajarkan nya.

Fenomena lain berdasarkan pengalaman penulis dalam mengajar terungkap bahwa siswa terkadang mengalami kesulitan dalam menyelesaikan soal-soal yang diberikan. Hal tersebut disebabkan oleh cara belajar yang hanya cenderung menghafal konsep bukan memahami konsep. Di samping itu, siswa kurang mampu mengkonstruksi atau mengaitkan konsep-konsep IPS yang dipelajarinya dengan situasi dunia nyata mereka.Akibatnya, hasil belajar IPS yang diperoleh lebih rendah dibanding dengan mata pelajaran lainnya.

Dalam proses pembelajaran diperlukan pembelajaran yang efektif agar dalam belajar akan terasa mudah dan menyenangkan. Untuk itu, diperlukan suatu metode pembelajaran yang lebih memberdayakan siswa.Sebuah metode pembelajaran yang tidak mengharuskan siswa menghafal fakta-fakta tanpa memahami maknanya, tetapi mendorong siswa untuk menemukan dan mengkonstruksi pengetahuan di benak mereka sendiri.

Salah satu metode pembelajaran yang cocok digunakan untuk mewujudkan hal yang dimaksud adalah metode inkuiri, karena metode inkuiri merupakan konsep belajar yang menuntut siswa menemukan sendiri dan membantu guru mengaitkan materi yang diajarkannya dengan situasi dunia nyata siswa dan mendorong siswamembuat hubungan antara pengetahuan yang dimilikinya dengan penerapannya dalam kehidupan mereka sebagai anggota keluarga dan masyarakat. Dengan konsep ini, maka pembelajaran diharapkan lebih bermakna bagi siswa. Proses pembelajaran berlangsung alamiah dalam bentuk kegiatan siswa bekerja dan mengalami, bukan transfer pengetahuan dari guru ke siswa (Upu, 2003).

Dalam pembelajaran IPS dengan metode inkuiri (menemukan), guru dituntut selalu merancang kegiatan pembelajaran yang merujuk pada kegiatan menemukan sesuatu materi yang diajarkan.Teknik ini berkaitan dengan masalah prosedur mengajar yang menekankan belajar individu, yaitu murid secara individual memanipulasi objek dan melaksanakan eksperimen sendiri.Artinya, murid sendiri yang menemukan konsep dan membuat generalisasi.Prosedur pelaksanaan strategi ini dimulai dari menemukan terpimpin yang berlanjut dengan menemukan sendiri.

Dengan penggunaan metode inkuiri dapat juga membuat para peserta didik tidak pasif di tempatnya dan juga tidak membuat peserta didik merasa bosan atau jenuh bila berada di dalam kelas.Berdasarkan uraian tersebut, maka dilakukan penelitian dengan judul "Penerapan Metode Inkuiri dalam Peningkatan Hasil Belajar IPS pada Pokok Bahasan Kegiatan Ekonomi Penduduk Siswa Kelas VI SD Inpres 10/73 Welado Kabupaten Bone.

\section{METODE PENELITIAN}

Penelitian ini menggunakan pendekatan kualitatif. Jenis penelitian ini adalah Penelitian Tindakan Kelas (Classroom Action Research) yang bertujuan memecahkan masalah yang bersumber dari proses peningkatan hasil belajar IPS melalui metode inkuiri pada siswa kelas VI SD Inpres 10/73 Welado Kabupate Bone. Alur penelitian ini, yaitu perencanaan, pelaksanaan tindakan, observasi/evaluasi, dan refleksi.

Fokus masalah penelitian ini sebagai berikut:

1. Penerapan metode inkuiri adalah cara guru mengajarkan satu pokok bahasan yang berorientasi pada penemuan sendiri, mengkonstruksi pengetahuan, dan menghubungkannya dengan situasi dunia nyata siswa.

2. Hasil belajar IPS adalah tingkat penguasaan pelajaran IPS setelah penerapan pembelajaran metode inkuiri pada akhir setiap siklus sedangkan aktivitas belajar yaitu seluruh kegiatan siswa selama proses pembelajaran berlangsung.

Penelitian tindakan kelas ini dilaksanakan di kelas VI SD Inpres 10/73 Welado Kabupaten Bone Dengan populasi siswa kelas VI SD Inpres 10/73 Welado Kabupaten Bone sebanyak 25 siswa.

Adapun teknik pengumpulan data yang dilakukan dalam penelitian tindakan ini sebagai berikut:

1. Data peningkatan penguasaan materi diambil dari soal yang diberikan pada tiap akhir siklus 
kemudian dibandingkan di tiap siklus. Pada tes siklus diberikan soal sebanyak 10 nomor kemudian dianalisis dengan menggunakan skor.

2. Data aktivitas belajar siswa selama proses belajar mengajar di kelas diperoleh dengan menggunakan lembar observasi. Data aktivitas siswa diamati oleh 2 orang observator dengan menggunakan lembar observasi selama proses belajar mengajar berlangsung.

Alat pengumpul data dalam penelitian ini sebagai berikut.

1. Tes, menggunakan butir soal/instrumen soal untuk mengukur hasil belajar siswa.

2. Observasi, menggunakan lembar observasi untuk mengukur tingkat aktivitas siswa dalam proses belajar mengajar Ilmu Pengetahuan Sosial (Lembar observasi terlampir.

Penelitian ini terdiri dari dua variabel, yaitu pertama variabel bebas pembelajaran inkuiri.Kedua variabel terikat yaitu hasil belajar IPS siswa kelas VI SD Inpres 10/73 Welado Kabupaten Bone.

Penelitian tindakan kelas (Classroom Action Research) diawali dengan refleksi awal yang dilakukan oleh peneliti untuk mengenali dan mengetahui kondisi awal atau mencari masalah pada tempat yang dijadikan objek penelitian.Secara umum penelitian tindakan kelas memiliki desain dengan empat langkah utama, yaitu perencanaan, tindakan, observasi, evaluasi, dan refleksi.

Desain penelitian tindakan kelas merupakan proses perbaikan secara terus-menerus dan suatu tindakan yang masih mengandung kelemahan sebagaimana hasil refleksi menuju ke arah yang semakin sempurna. Penelitian ini terdiri atas dua siklus, pada akhir setiap siklus dilakukan evaluasi hasil belajar.Tiap siklus berlangsung selama 4 kali pertemuan, tes tertulis dilaksanakan pada pertemuan keempat.

Data yang diperoleh selanjutnya dianalisis dengan menggunakan analisis statistik deskriptif kualitatif dan kuantitatif. Analisis kualitatif digunakan untuk mendeskripsikan keaktifan belajar siswa yang diketahui dan hasil pengamatan aktivitas siswa di kelas sedangkan analisis kuantitatif digunakan untuk mendeskripsikan hasil belajar IPS siswa yang diketahui dan hasil penelitian setiap siklus.

1. Proses Pembelajaran

Data tentang keterampilan proses yang berlangsung diperoleh melalui observasi aktivitas siswa saat pembelajaran berlangsung, yang dianalisis untuk mendeskripsikan pelaksanaan indikator tiap aspek yang tercantum dalam lembar observasi aktivitas siswa terlaksana atau tidak.

2. Produk Pembelajaran

Data produk pembelajaran berupa tes hasil belajar siswa dianalisis dengan menggunakan skor berdasarkan pada penilaian acuan patokan (PAP) yang mungkin dicapai siswa yang selanjutnya dikelompokkan ke dalam lima kategori, yaitu sangat tinggi, tinggi, sedang, rendah, dan sangat rendah (Sudjana, 2002: 46).

\section{HASIL DAN PEMBAHASAN}

\section{Siklus I}

Penelitian ini dilaksanakan pada kelas VI SD Inpres 10/73 Welado Kabupaten Bone dengan jumlah siswa sebanyak 25 orang. Siswa ini terbagi dalam 6 kelompok.Satu kelompok terdiri dari 5 orang dan didampingi oleh 2 orang pengamat(observator).Pelaksanaan penelitian berlangsung dalam 3 kali pertemuan, tes tertulis dilaksanakan pada pertemuan keempat.Adapun materi pelajaran pada penelitian iniadalah Kegiatan Ekonomi Penduduk.

\section{a. Hasil Observasi Aktivitas Siswa}

Pengamatan aktivitas siswa digunakan lembar observasi untuk mencatat kejadian yang terjadi selama proses belajar mengajar. Hasil observasi aktivitas siswa kelas VI SD Inpres 10/73 Welado Kabupaten Bone pada siklus I ditampilkan dalam tabel berikut:

Tabel 4.1 Observasi aktivitas siswa pada siklus I

\begin{tabular}{llccccccc}
\hline No. & Aktivitas & & \multicolumn{2}{c}{ Pertemuan I } & \multicolumn{2}{c}{ Pertemuan II } & \multicolumn{2}{c}{ Pertemuan III } \\
\cline { 2 - 8 } & & Ensi & $\begin{array}{c}\text { Persen- } \\
\text { tase }(\%)\end{array}$ & $\begin{array}{c}\text { Freku- } \\
\text { Ensi }\end{array}$ & $\begin{array}{c}\text { Persen- } \\
\text { tase }(\%)\end{array}$ & $\begin{array}{c}\text { Freku- } \\
\text { ensi }\end{array}$ & $\begin{array}{c}\text { Persen- } \\
\text { tase (\%) }\end{array}$ \\
\hline $\begin{array}{l}\text { 1. } \\
\text { Menyimak } \\
\text { guru. }\end{array}$ & pengarahan & 3 & 50 & 4 & 66.66 & 5 & 83.33 \\
\hline 2. & $\begin{array}{l}\text { Kerjasama } \\
\text { kelompoknya. }\end{array}$ & di & 3 & 50 & 4 & 66.66 & 4 & 66.66 \\
\hline 3. & $\begin{array}{l}\text { Kelompok } \\
\text { membaca. }\end{array}$ & aktif & 4 & 66.66 & 4 & 66.66 & 4 & 66.66 \\
\hline
\end{tabular}




\begin{tabular}{|c|c|c|c|c|c|c|}
\hline 4. Merumuskan masalah. & 2 & 33.33 & 4 & 66.66 & 4 & 66.66 \\
\hline $\begin{array}{ll}\text { 5. } & \text { Menemukan atau } \\
& \text { menyelesaikan masalah } \\
\end{array}$ & 2 & 33.33 & 4 & 66.66 & 4 & 66.66 \\
\hline $\begin{array}{l}\text { 6. Mengajukan pertanyaan } \\
\text { dengan benar dan tepat. }\end{array}$ & 3 & 50 & 5 & 83.33 & 5 & 83.33 \\
\hline $\begin{array}{l}\text { 7. } \begin{array}{l}\text { Memberikan } \\
\text { menjawab atau } \\
\text { tanggapan }\end{array} \text { pertanyaan/ } \\
\end{array}$ & 3 & 50 & 4 & 66.66 & 4 & 66.66 \\
\hline $\begin{array}{ll}\text { 8. } & \begin{array}{l}\text { Bereksperimen } \\
\text { berkreasi. }\end{array}\end{array}$ & 1 & 16.66 & 3 & 50 & 4 & 66.66 \\
\hline $\begin{array}{l}\text { 9. } \begin{array}{l}\text { Memunculkan ide dan } \\
\text { gagasan }\end{array} \\
\end{array}$ & 1 & 16.66 & 3 & 50 & 4 & 66.66 \\
\hline $\begin{array}{l}\text { 10. Tanggung jawab individu } \\
\text { dan Kelompok }\end{array}$ & 4 & 66.66 & 4 & 66.66 & 4 & 66.66 \\
\hline
\end{tabular}

Sumber : Data Diolah, Tahun 2017

Keterangan:

$\begin{array}{ll}\text { Kategori } & \text { Rentang } \\ \text { Sangat tinggi } & (85-100 \%) \\ \text { Tinggi } & (65-84 \%) \\ \text { Sedang } & (55-64 \%) \\ \text { Rendah } & (35-54 \%) \\ \text { Sangat Rendah } & (0-34 \%)\end{array}$

Berdasarkan tabel hasil observasi di atas, maka dapat disimpulkan bahwa:

1. Pada pertemuan I belum tampak adanya keseriusan siswa dalam mengikuti pembelajaran. Hal ini terlihat pada indikator perilaku yang tidak relevan dalamkegiatan belajar mengajar, ada beberapa siswa yang terlibat di dalam indikator tersebut.

2. Pada pertemuan II sudah ada peningkatan dan keantusiasan siswa dalam mengikuti pembelajaran. Hal ini terlihat pada beberapa indikator yang mengalami peningkatan persentase.

3. Pada pertemuan III peningkatan dan keantusiasan siswa dalam mengikuti pembelajaran semakin meningkat. Hal ini terlihat pada beberapa indikator yang mengalami peningkatan persentase. Selain itu, juga pada indikator perilaku yang tidak relevan sudah mengalami penurunan persentase.

Aktivitas siswa pada siklus I khususnya pada pertemuan ketiga ini sudah menunjukkan adanya keseriusan dan keantusiasan siswa dalam mengikuti pembelajaran di dalam kelasnya dibandingkan dengan pertemuan pertama dan kedua. Hal ini terlihat pada indikator memberi tanggapan, kerjasama di kelompoknya, menjawab pertanyaan dengan benar dan tepat, dan menemukan serta menyelesaikan masalah. Untuk indikator lainnya, yaitu mengajukan pertanyaan dan mengajukan pertanyaan yang relevan hanya sebagian siswa saja yang terlibat di dalamnya, ini disebabkan konsentrasi siswa yang belum terfokus dengan suasana belajar baru yang menuntut siswa untuk aktif bekerjasama di kelompoknya dan juga siswa belum mampu dan berani menemukan dan bereksperimen juga masih kurang, sehingga masih ada siswa kelihatan bingung dan bersikap pasif. Hal inilah yang menjadi bahan refleksi untuk pelaksanaan siklus II.

\section{b. Hasil Belajar Siswa}

Hasil belajar siswa diperoleh dan nilai ujian yang dilaksanakan setelah mengikuti proses belajar mengajar dengan menggunakan metode inkuiri. Data hasil tes disajikan dalam tabel berikut:

Tabel 4.2 Distribusi frekuensi persentase kategori hasil belajar siklus I

\begin{tabular}{cccc}
\hline $\begin{array}{c}\text { Interval } \\
\text { Nilai }\end{array}$ & Kualifikasi Frekuensi & Persentase \% \\
\hline $81-100$ & $\begin{array}{c}\text { Tinggi } \\
\text { Sekali }\end{array}$ & 1 & 2,9 \\
\hline $61-80$ & Tinggi & 15 & 61 \\
\hline $41-60$ & Sedang & 5 & 25 \\
\hline $21-40$ & Rendah & 4 & 11, \\
\hline $0-20$ & $\begin{array}{c}\text { Sangat } \\
\text { Rendah }\end{array}$ & - & - \\
\hline & & 25 & 100 \\
\hline
\end{tabular}

Sumber: Data Diolah Tahun 2017

Data di atas menunjukkan bahwa secara umum penguasaan siswa terhadap materi yang disajikan melalui penggunaan metode inkuiri belum maksimal. Hal ini terlihat pada frekuensi hasil belajar siswa yang masih berada pada kategori 24 rendah dengan persentase $11,1 \%$ dari keseluruhan siswa. Selain itu, masih terlihat 
adanya hasil belajar siswa yang berada pada kategori sedang dengan persentase $25 \%$, dan $61 \%$ hasil belajar siswa dikategorikan tinggi, dan 2,9\% hasil belajar siswa di kategorikan sangat tinggi. Hasil belajar siswa pada siklus I masih berada pada kategori sedang dengan rata-rata 67,7 hal inilah yang menjadi salah satu bahan refleksi untuk pelaksanaan siklus II.

\section{c. Refleksi}

Upaya yang dilakukan untuk meningkatkan hasil belajar IPS siswa kelas VI SD Inpres 10/73 Welado Kabupaten Bone dengan menggunakan metode inkuiri, guru/peneliti dalam hal ini tidak terlepas dari perhatian yang besar terhadap perubahan sikap siswa, keaktifan siswa, dan tanggapan siswa terhadap proses, pembelajaran yang dialaminya. Hal ini dapat dilihat dari hasil observasi yang dilakukan selama pelaksanaan tindakan.

Aktivitas guru pada siklus I masih kurang.Banyak komponen yang seharusnya diterapkan guru sebagai upaya meningkatkan aktivitas belajar siswa terutama dengan menggunakan metode inkuiri yang tidak diterapkan dengan maksimal oleh guru.

Kegiatan siswa pada siklus satu ini, semangat dan perhatian siswa dalam proses pembelajaran ini masih kurang. Hal ini terlihat dari kurangnya perhatian serius dari siswa sehingga dalam menanggapi materi, merumuskan masalah, menemukan/menyelesaikan masalah, serta kurang mampu melakukan eksperimen.Sikap siswa pada umumnya masih kurang memberikan tanggapan atau respons positif terhadap metode yang disajikan.

Pada saat guru memantau siswa dalam mempelajari materi dan melakukan eksperimen ternyata pada umumnya hanya satu dua siswa yang benar-benar aktif pada setiap kelompok, hanya sebagian yang menjawab tuntas dan yang lainnya menjawab sebagian saja. Selain itu, ditemukan adanya siswa yang melakukan aktivitas yang tidak ada hubungannya dengan pelajaran seperti ngobrol sesama teman dan mengerjakan tugas pelajaran yang lain.

Namun demikian, selama kegiatan berlangsung hingga akhir pertemuan siklus satu, sudah ditemukan bentuk tersendiri sesuai yang diinginkan.Hal ini dapat dilihat dari aktivitas belajar untuk menemukan masalah yang mengalami peningkatan. Misalnya, siswa mulai berusaha untuk menemukan sendiri masalah-masalah yang ada dan diselesaikan sendiri, mulai tampak kekreatifan siswa dalam menemukan dan merumuskan masalah, mulai bereksperimen untuk menemukan cara lain menemukan masalah. Segala yang diinginkan untuk dicapai pada siklus I ini masih kurang dan memerlukan pembenahan di siklus II.

Selain itu, berdasarkan hasil observasi mengenai model pengajaran ini, maka ditemukan hal lain yang perlu diperhatikan pada siklus II adalah:

1. Tuntunan kepada siswa harus ditingkatkan.

2. Penguatan dan motivasi yang diberikan kepada siswa yang mampu menemukan, bereksperimen dengan tepat, dan menyelesaikan masalah perlu ditingkatkan.

3. Struktur dan variasi kelas (setting) perlu diubah dengan membentuk kelompokbelajar.

4. Mengubah setting tempat duduk dan jarak bangku antar tiap kelompok agarkejadian-kejadian yang kurang positif dapat diminimalisir.

5. Memberikan kebebasan kepada siswa berkreasi dan bereksperimen untuk menemukan cara menyelesaikan suatu persoalan.

6. Siswa yang dianggap mampu diharapkan membantu temannya sehingga terjadi tutor sebaya.

\section{Siklus II}

Penelitian ini dilaksanakan pada kelas VI SD Inpres 10/73 Welado Kabupaten Bone dengan jumlah siswa sebanyak 25 orang.Siswa ini terbagi dalam 6 kelompok. Satu kelompok terdiri dari 5 orang dan didampingi oleh 2 orang pengamat(observator). Pelaksanaan penelitian berlangsung dalam 4 kali pertemuan, tes tertulis dilaksanakan pada pertemuan keempat. Adapun materi pelajaran pada penelitian ini adalah kegiatan ekonomi penduduk.

\section{a. Hasil Observasi Aktivitas Siswa}

Pengamatan aktivitas siswa digunakan lembar observasi untuk mencatat kejadian-kejadian yang terjadi selama proses belajar mengajar. Hasil observasi aktivitas siswa kelas VI SD Inpres 10/73 Welado Kabupaten Bone pada siklus II ditampilkan dalam tabel berikut: 
Tabel 4.3 Observasi aktivitas siswa pada siklus II

\begin{tabular}{|c|c|c|c|c|c|c|}
\hline \multirow[t]{2}{*}{ No. Aktivitas } & \multicolumn{2}{|c|}{ Pertemuan I } & \multicolumn{2}{|c|}{ Pertemuan II } & \multicolumn{2}{|c|}{ Pertemuan III } \\
\hline & $\begin{array}{l}\text { Freku- } \\
\text { Ensi }\end{array}$ & $\begin{array}{l}\text { Persen- } \\
\text { tase }(\%)\end{array}$ & $\begin{array}{l}\text { Freku- } \\
\text { Ensi }\end{array}$ & $\begin{array}{l}\text { Persen- } \\
\text { tase }(\%)\end{array}$ & $\begin{array}{l}\text { Freku- } \\
\text { ensi }\end{array}$ & $\begin{array}{l}\text { Persen- } \\
\text { tase } \\
(\%)\end{array}$ \\
\hline 1. Menyimak pengarahan guru. & 6 & 100 & 6 & 100 & 6 & 100 \\
\hline 2. Kerjasama di kelompoknya. & 5 & 83.33 & 6 & 100 & 6 & 100 \\
\hline 3. Kelompok aktif membaca. & 5 & 83.33 & 5 & 83.33 & 6 & 100 \\
\hline 4. Merumuskan masalah. & 5 & 83.33 & 5 & 83.33 & 5 & 83.33 \\
\hline $\begin{array}{l}\text { 5. Menemukanataumenyelesaikan } \\
\text { masalah }\end{array}$ & 5 & 83.33 & 5 & 83.33 & 5 & 83.33 \\
\hline $\begin{array}{l}\text { 6. Mengajukanpertanyaandenganbenar } \\
\text { dan tepat. }\end{array}$ & 5 & 83.33 & 5 & 83.33 & 5 & 83.33 \\
\hline $\begin{array}{l}\text { 7. Memberikanataumenjawabpertanyaa } \\
\text { n/tanggapan }\end{array}$ & 5 & 83.33 & 5 & 83.33 & 5 & 83.33 \\
\hline 8. Bereksperimen dan berkreasi. & 4 & 66.66 & 5 & 83.33 & 5 & 83.33 \\
\hline 9. Memunculkan ide dan gagasan & 4 & 66.66 & 4 & 66.66 & 5 & 83.33 \\
\hline $\begin{array}{l}\text { 10. Tanggung jawab individu dan } \\
\text { Kelompok }\end{array}$ & 6 & 100 & 6 & 100 & 5 & 83.33 \\
\hline
\end{tabular}

Sumber : Data Diolah, Tahun 2017

Keterangan

Kategori

SangatTinggi

Tinggi

Sedang

Rendah

SangatRendah

Aktivitas siswa pada siklus II sudah terlihat dengan jelas adanya keseriusandan keantusiasan siswa dalam mengikuti pelajaran.Hal ini terlihat pada beberapaindikator mengalami peningkatan frekuensi di mana hampir semua siswa ikut terlibatdi dalamnya.Hal ini disebabkan oleh minat belajar siswa dengan menggunakanmetode inkuiri mulai muncul. Untuk indikator yang tidak relevan dengan kegiatan belajar mengajar masih ada siswa yang terlibat, hal ini terjadi pada saat siswa melakukan proses inkuiri atau proses menemukan sesuatu.

\section{b. Hasil Belajar Siswa}

Tabel 4.4 Distribusi frekuensi persentase kategori hasil belajar siklus II

Interval Kualifikasi Frekuensi Persentase \%

Nilai

\begin{tabular}{cccc}
\hline $81-100$ & $\begin{array}{c}\text { Tinggi } \\
\text { Sekali }\end{array}$ & 5 & 22,2 \\
\hline $61-80$ & Tinggi & 20 & 77,8 \\
\hline $41-60$ & Sedang & - & - \\
\hline $21-40$ & Rendah & - & - \\
\hline $0-20$ & Sangat & - & - \\
\hline
\end{tabular}

\begin{tabular}{lll}
\hline \multicolumn{3}{c}{ Rendah } \\
\hline & 25 & 100 \\
\hline
\end{tabular}

Sumber : Data Diolah, Tahun 2017

Data pada tabel di atas menunjukkan adanya peningkatan hasil belajar siswa pada pelaksanaan siklus II. Hal ini terlihat pada frekuensi hasil belajar siswa yang berada pada kategori tinggi mengalami peningkatan dengan persentase $77,8 \%$ dan kategori sangat tinggi dengan persentase $22,2 \%$, dan sudah tidak ada siswa yang memperoleh hasil belajar pada kategori rendah dan sangat rendah. Hasil belajar siswa pada siklus II berada pada kategori tinggi dengan rata-rata 84,1.

Hasil di atas menunjukkan bahwa hasil belajar siswa yang belajar melalui metode inkuiri mengalami peningkatan dari pretest, siklus I sampai siklus II. Hal ini dapat terlihat dari rata-rata kelas yang diperoleh siswa sebelum belajar dengan menggunakan metode inkuiri yaitu 48,8, pada siklus I 67,7, dan pada siklus II meningkat menjadi 84,1 .

\section{c. Refleksi}

Berdasarkan pelaksanaan pembelajaran dalam upaya meningkatkan hasil belajar IPS siswa kelas VI SD Inpres 10/73 Welado Kabupaten Bone dengan menggunakan metode inkuiri, terdapat banyak perubahan dibandingkan dengan siklus I. Pertama-tama, perubahan sikap siswa yang meningkat, keaktifan siswa, dan 
tanggapan siswa terhadap proses pembelajaran yang dialaminya sangat meningkat.

Aktivitas guru juga pada siklus II sangat bagus sehingga banyak implikasinya terhadap pembelajaran.Misalnya, kegiatan siswa pada siklus satu ini sangat bagus, siswa bersemangat dan memperhatikan pembelajaran.Adanya perhatian yang serius dari siswa dalam menanggapi materi, siswa aktifmerumuskan masalah, siswa aktif menemukan/menyelesaikan masalah, serta mampu melakukan eksperimen.Sikap siswa pada umumnya rata-rata bagus dalam memberikan tanggapan atau respons positif terhadap metode yang disajikan.

Pada dasarnya, rata-rata siswa dapat mempelajari materi dan melakukan eksperimen, rata-rata mampu menjawab tuntas masalah yang ada. Selain itu, siswa yang melakukan aktivitas yang tidak ada hubungannya dengan pelajaran seperti ngobrol sesama teman dan mengerjakan tugas pelajaran yang lain sangat berkurang.

Intinya, siswa mampu menemukan sendiri masalah-masalah yang ada dan diselesaikan sendiri, mulai tampak kekreatifan siswa dalam menemukan dan merumuskan masalah, mampu berkesperimen untuk menemukan cara lain menemukan masalah.

Aspek lain yang berpengaruh terhadap keberhasilan pembelajaran pada siklus II adalah:

1. Guru memberikan tuntunan kepada siswa.

2. Guru memberikan penguatan dan motivasi kepada siswa yang mampu menemukan, bereksperimen dengan tepat, dan menyelesaikan masalah perlu ditingkatkan.

3. Guru mengubah struktur dan variasi kelas (setting) dengan membentuk kelompok belajar.

4. Guru mengubah setting tempat duduk dan jarak bangku antar tiap kelompok agar kejadian-kejadian yang kurang positif dapat diminimalisir.

5. Guru memberikan kebebasan kepada siswa berkreasi dan bereksperimen untuk menemukan cara menyelesaikan suatu persoalan.

6. Siswa yang dianggap mampu membantu temannya sehingga terjadi tutor sebaya.

Berdasarkan penyajian hasil analisis data dapat diuraikan peningkatan hasil belajar IPS siswa kelas VI SD Inpres 10/73 Welado Kabupaten Bone dengan menggunakan metode inkuiri. Peningkatan yang dimaksud, yaitu peningkatan proses dan hasil belajar IPS siswa kelas VI SD Inpres 10/73 Welado Kabupaten Bone dengan menggunakan metode inkuiri.
Proses belajar mengajar IPS berdasarkan hasil pengamatan pada keadaan atau kondisi awal menunjukkan adanya beberapa masalah: (1) kegiatan belajar mengajar kurang memberikan kesempatan kepada siswa untuk menemukan sendiri dan memecahkan masalah, (2) kurangnya kesempatan yang diberikan kepada siswa untuk mengembangkan pengetahuannya, (3) guru dalam mengajar kurang memahami penggunaan metode pembelajaran yang tepat dan sesuai dengan konsep yang diajarkan, (4) guru dalam mengajar masih menggunakan metode konvesional dengan alasan cukup sederhana dan mudah dilakukan, (5) tidak ada penggunaan media pembelajaran yang dapat membantu siswa dalam memahami suatu konsep. Berdasarkan hal ini, maka tidak mengherankan jika kemudian hari diperoleh hasil belajar yang masih kurang memuaskan.

Dilihat dari permasalahan yang terjadi, dilaksanakan kegiatan proses belajar mengajar dengan menerapkan metode inkuiri. Kegiatan dilaksanakan dalam dua tahapan atau siklus yang berkesinambungan. Data yang diambil ada dua macam, yaitu data proses pembelajaran yang diambil saat kegiatan belajar mengajar berlangsung, meliputi data aktivitas siswa dan data hasil belajar siswa yang diambil pada akhir setiap siklus dengan menggunakan tes tertulis. Data hasil aktivitas siswa ditampilkan dalam tabel 3 dan 5, dan data hasil belajar siswa ditampilkan dalam tabel 4 dan 6 .

Format atau lembar pengamatan aktivitas siswa berisi aspek-aspek keterampilan proses dengan indikator yang sama untuk setiap aspek meliputi: (1) menyimak pengarahan guru; (2) kerjasama di kelompoknya; (3) murid membaca, menemukan, menyelesaikan masalah, dan memberikan tanggapan; (4) mengajukan pertanyaan dan menjawab pertanyaan dengan benar dan tepat; (5) murid bereksperimen dan berkreasi dan selalu memunculkan ide dan gagasan; (6) tanggung jawab individu dan kelompok untuk menemukan dan cara menyelesaikan masalah.

Berdasarkan hasil pengamatan menunjukkan ketercapaian indikator dalam beberapa aspek dengan melihat frekuensi siswa yang aktif dalam setiap aspek.Pada siklus I menunjukkan masih kurangnya keseriusan dan keantusiasan siswa pada beberapa indikator aktivitas siswa. Hal ini terlihat dan proses belajar mengajar di mana siswa masih kurang yang mampu menemukan, memunculkan ide, bereksperimen, dan memecahkan masalah. Selain 
itu, belum tercapainya tujuan pembelajaran yang diharapkan dan belum sesuai dengan langkah-langkah metode inkuiri.Hal ini disebabkan oleh guru biasanya menggunakan metode ceramah untuk menyampaikan materi melalui penjelasan dan hanya guru yang aktif menemukan dan memecahkan sendiri permasalahan siswa terkadang hanya menulis dan mendengar penjelasan guru.Pada siklus II, sudah menunjukkan keseriusan dan keantusiasan siswa dalam mengikuti pembelajaran.Hal ini tampak dari keaktifan siswa dalam menemukan, memunculkan ide, berani bereksperimen, dan mampu memecahkan masalah yang ada, saling melontarkan pertanyaan baik terhadap guru maupun dengan temannya sendiri.Hal ini menunjukkan ketercapaian pembelajaran sudah sesuai dengan langkah-langkah metode inkuiri.

Hasil belajar IPS sebelum mengikuti pembelajaran dengan metode inkuiri termasuk kategori sedang, yaitu $63,9 \%$ dengan nilai rata-rata 48,8, setelah pelaksanaan siklus I sudah ada pada kategori tinggi. Hal ini didukung oleh persentase siswa, yaitu $61 \%$ dengan nilai rata-rata 67,7 . Hal ini diasumsikan sebagai akibat adanya perubahan model mengajar guru yang menuntut adanya keaktifan siswa dalam belajar dengan menggunakan metode inkuiri. Dari hasil belajar siklus I ini menunjukkan peningkatan hasil belajar belum sesuai yang diharapkan, sedangkan pada pelaksanaan siklus II hasil belajar siswa memperlihatkan persentase tertinggi yaitu 77,8 \% dengan skor rata-rata 84,1. Berdasarkan data ini dapat dikatakan bahwa hasil belajar siswa melalui penggunaan metode inkuiri mengalami peningkatan dari hasil belajar pada pretest ke hasil belajar siklus I, dan hasil belajar pada siklus II yang berada pada kategori tinggi.

Penggunaan metode inkuiri dalam pembelajaran ini merupakan daya tarik utama bagi siswa dalam melakukan aktivitas pembelajaran, karena penggunaanmetode inkuiri merupakan cara baru bagi mereka dalam memperoleh dan mengembangkan pengetahuannya, di mana siswa lebih aktif di dalam pembelajarankarena siswa dituntut untuk mampu menemukan, membangun pengetahuannya,merumuskan masalah. Hal ini sesuai dengan pernyataan yang dibuat olehTolla(1997: 65) mengemukakan bahwa:

Strategi pengajaran inkuiri termasuk strategi pengajaran yang berpusat pada siswa, yaitu siswa secara individual memanipulasikan objek dan melaksanakan eksperimen
sendiri.Artinya, siswa sendiri yang menemukan konsep dan membuat generalisasi.Prosedur pelaksanaan strategi ini dimulai dari penemuan terpimpin yang berlanjut pada menemukan sendiri.

Sejalan dengan hal tersebut, Hastuti (1997: 148) juga menyatakan bahwa:

Salah satu strategi pengajaran yang berpusat pada siswa di SD.Strategi ini dapat menolong siswa menghubungkan disiplin intelektual dan keterampilan intelektual. Melalui latihan- latihan dengan memberikan pertanyaan, menyuguhkan informasi, siswa didorong untuk berusaha mencari, mencoba sendiri, dan akhirnya menemukan sesuai dengan keadaan dan kapasitas yang digunakan untuk mencapai suatu tujuan tertentu.

Berdasarkan hasil proses pengamatan menunjukkan adanya peningkatan setelah pemberian tindakan berupa penggunaan metode inkuiri dalam pembelajaran, secara umum dapat dikatakan penguasaan siswa terhadap materi cukup baik.

\section{SIMPULAN DAN SARAN}

Berdasarkan penyajian hasil analisis data dan pembahasan, dapat disimpulkan tentang peningkatan hasil belajar IPS siswa kelas VI SD Inpres 10/73 Welado Kabupaten Bone dengan menggunakan metode inkuiri.Hasil penelitian menunjukkan bahwa penggunaan metode inkuiri meningkatkan hasil belajar IPS siswa kelas VI SD Inpres 10/73 Welado Kabupaten Bone .Peningkatannya tampak pada nilai yang berada pada kategori rendah meningkat menjadi nilai yang berkategori tinggi.Selanjutnya, nilai rata-rata berada pada kategori rendah meningkat ke kategori kategori tinggi.

$$
\text { Berdasarkan kesimpulan yang }
$$

dikemukakan, maka saran yang diajukan oleh penulis adalah diharapkan kepada guru kelas agar dapat menggunakan metode inkuiri dalam proses belajar mengajar karena metode ini menuntut siswa lebih aktif dalam belajar untuk menemukan dan membangun pengetahuannya. Selain itu, metode inkuiri mendidik siswa menghubungkan pengetahuan yang diperoleh dengan dunia nyata. Dengan demikian, pembelajaran dan prestasi siswa di dalam kelas dapat berjalan dengan baik dan mendapat hasil belajar sesuai dengan apa yang telah di harapkan oleh para guru. 
JIKAP PGSD: Jurnal Ilmiah Ilmu Kependidikan

Diharapkan juga dengan menggunakan metode inkuiri di dalam kelas membuat para siswa lebih berani untuk mengeluarkan pendapatnya sendiri dan tidak membuat suasana kelas menjadi jenuh dan membosankan jika guru hanya menggunakan metode yang sifatnya masih konvesional.

\section{DAFTAR RUJUKAN}

Adrian. 2008. Metode Mengajar Berdasarkan Tipologi Siswa.WWW.Google.Corn. Diakses 26 Agustus 2008

Djamarah, Syaiful Bachri. 2005. Guru dan Anak Didik. Jakarta. Rineka Cipta.

Gulo,W. 2002. StrategiBelajar Mengajar. Jakarta:GramediaWidiasarana Indonesia.

Hamalik, Oemar. 2001. Proses Belajar Mengajar. Bandung: Bumi Aksara.

Hastuti, Sri. 1997. Strategi Belajar Mengajar Bahasa Indonesia.Jakarta: Depdikbud.

Kunandar.2008. Langkah Mudah Penelitian Tindakan Kelas Sebagai Pengembangan Profesi Guru.Jakarta. Raja Grafindo Persada.

Muhibbin, Syah. 1995. Psikologi Pendidikan Suatu Pendekatan Baru. Bandung: Remaja Rosdakarya.

Nasution, S. A. M. 2005. Teknologi Penelitian. Jakarta: Bumi Aksara..

Nurhadi. 2002. Proyek Peningkatan Mutu SLTP. Jakarta: Depdiknas, Direktorat Jenderal Pendidikan Lanjutan Pertama.

Roestiyah, N. K. 2001. Strategi Belajar Mengajar. Jakarta. Rineka Cipta.

Sardinian. 2006. Interaksi \& Motivasi Belajar Mengajar. Jakarta: Raja Grafindo Persada.

Slameto.2003. Belajar dan Faktor-Faktor yang Mempengaruhinya. Jakarta: Rineka Cipta.

Umar, A. 2008.Penelitian Tindakan Kelas: Pengantar ke dalam Pemetaan Konsep dan Aplikasi. Makassar: Badan Penerbit UNM. 